




\section{RELEASE AUTHORIZATION}

\section{Document Number: WHC-SD-WM-LL-007, REV 0}

$\begin{array}{ll} & \text { Lessons Learned Report For The Radioactive Mixed } \\ \text { Document Title: } & \text { Waste Land Disposal Facility (Trench 31, Project W- }\end{array}$ 025)

Release Date: $\quad 6 / 20 / 95$

This document was reviewed following the procedures described in WHC-CM-3-4 and is:

APPROVED FOR PUBLIC RELEASE

WHC Information Release Administration Specialist:

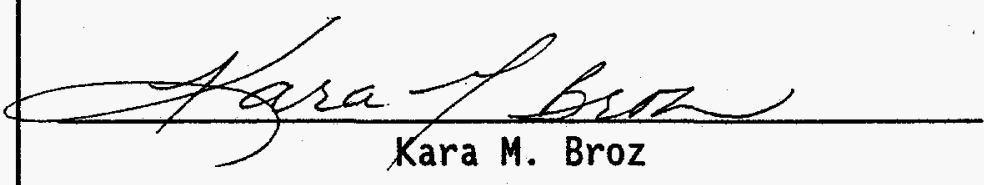

June 20,1995

TRADEMARK DISCLAIMER. Reference herein to any specific comercial product, process, or service by trade name, trademark, manufacturer, or otherwise, does not necessarily constitute or imply its endorsement, recommendation, or favoring by the United States Government or any agency thereof or its contractors or subcontractors.

This report has been reproduced from the best available copy. Available in paper copy and microfiche. Printed in the United States of America. Available to the U.S. Department of Energy and its contractors from:

U.S. Department of Energy

Office of Scientific and Technical Information (OSTI)

P.0. Box 62

Oak Ridge, TN 37831

Telephone: (615) 576-8401

Available to the public from:

U.S. Department of Commerce

National Technical Information Service (NTIS)

5285 Port Royal Road

Springfield, VA 22161

Telephone: (703) 487-4650

DISTRIBUTION OF THIS DOCUMENT IS UNLIMITED BS 


\section{DISCLAIMER}

Portions of this document may be illegible in electronic image products. Images are produced from the best available original document. 
2. Title

Lessons Learned Report For The Radioactive Mixed Waste Land Disposal Faci7ity (Trench 31. Project W-025)

5. Key Words

W-025, Radioactive Mixed Waste, Trench 31, Lessons Learned Report, Lessons Learned

\begin{tabular}{|l|c|}
$\begin{array}{l}\text { 3. Number } \\
\text { WHC-SD-WM-LL-007 }\end{array}$ & 4. Rev No. \\
6. Author \\
Name: Lee G. Irons \\
Signature \\
organization/Charge Code 87700
\end{tabular}

7. Abstract

See Executive Summary.

\section{DISCLAIMER}

This report was prepared as an account of work sponsored by an agency of the United States Government. Neither the United States Government nor any agency thereof, nor any of their employees, makes any warranty, express or implied, or assumes any legal liability or responsibility for the accuracy, completeness, or usefulness of any information, apparatus, product, or process disclosed, or represents that its use would not infringe privately owned rights. Reference herein to any specific commercial product, process, or service by trade name, trademark, manufacturer, or otherwise does not necessarily constitute or imply its endorsement, recommendation, or favoring by the United States Government or any agency thereof. The views and opinions of authors expressed herein do not necessarily state or reflect those of the United States Government or any agency thereof.

8.

RELEASE STAMP

OFFICIAL RELEASE BY WHS DATE JUN 19 1995

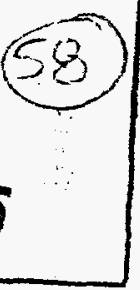


WHC-SD-WM-LL-007, Rev. 0

\title{
LESSONS LEARNED REPORT
}

FOR THE

\author{
RADIOACTIVE MIXED WASTE \\ LAND DISPOSAL FACILITY
}

(TRENCH 31, PROJECT W-025)

Prepared by the Westinghouse Hanford Company

for the

United States Department of Energy

Under Contract DE-AC06-87RL10930 
(This page left intentionally blank.) 


\section{TABLE OF CONTENTS}

EXECUTIVE SUMMARY ...................... 1

BACKGROUND ........................... 1

LESSONS LEARNED SUMMARY .................. 1

APPENDIX A: TRENCH 31 (PROJECT W-025) TIME LINE OVERVIEW . . . . . 3

APPENDIX B: PERSONNEL OPINIONS AND VIEWPOINTS . . . . . . 4

THINGS THAT WENT WELL ................. 4

THINGS THAT NEED IMPROVEMENT ............... 5

APPENDIX C: LESSONS LEARNED DEVELOPMENT ............ 8

1. PROJECT MANAGEMENT $\ldots \ldots . \ldots . \ldots$

2. REQUIREMENTS IMPLEMENTATION .............. 11

3. STARTUP PLANNING . . . . . . . . . . . . . . . 12

4. REQUIREMENTS IDENTIFICATION .............. . . . 12

5. OPERATIONAL READINESS ACTIVITIES ............. 14 


\section{ACRONYMS AND ABBREVIATIONS}

$\begin{array}{ll}\text { ATP } & \text { acceptance test procedure } \\ \text { CDR } & \text { conceptual design report } \\ \text { CRAs } & \text { criteria and review approaches } \\ \text { DDR } & \text { definitive design report } \\ \text { DOE } & \text { U.S. Department of Energy } \\ \text { ECN } & \text { engineering change notice } \\ \text { ETF } & \text { 200 Area Effluent Treatment Facility } \\ \text { FDC } & \text { functional design criteria } \\ \text { FHA } & \text { fire hazards analysis } \\ \text { FSAR } & \text { final safety analysis report } \\ \text { ISB } & \text { interim safety basis } \\ \text { LERF } & \text { Liquid Effluent Retention Facility } \\ \text { LLMW } & \text { Tow-level radioactive mixed waste } \\ \text { OTP } & \text { operational test procedure } \\ \text { POA } & \text { RA Plan of Action } \\ \text { PSAR } & \text { preliminary safety analysis report } \\ \text { QAPP } & \text { quality assurance program plan } \\ \text { RA } & \text { readiness assessment } \\ \text { RACS } & \text { requirements, assumptions, and commitments } \\ \text { RCRA } & \text { Resource Conservation and Recovery Act } \\ \text { RL } & \text { DOE Richland Operations Office } \\ \text { RLID } & \text { RL Implementing Directive } \\ \text { RT } & \text { Readiness Assessment Team } \\ \text { SAR } & \text { safety analysis report } \\ \text { S/RID } & \text { standards/requirements identification document } \\ \text { SWBG } & \text { Solid Waste Burial Grounds } \\ \text { SWD } & \text { Solid Waste Disposal } \\ \text { SWM } & \text { Solid Waste Management } \\ \text { TFS\&O } & \text { Tank Farms Surveillance and Operations } \\ \text { TSR } & \text { technical safety requirement } \\ \text { TWRS } & \text { Tank Waste Remediation System } \\ \text { USQ } & \text { unreviewed safety question } \\ \text { WAC } & \text { Washington State Administrative Code } \\ \text { WAP } & \text { waste analysis plan } \\ \text { WHC } & \text { Westinghouse Hanford Company } \\ & \\ & \end{array}$




\section{EXECUTIVE SUMMARY}

\section{BACKGROUND}

Project $W-025$ involves a modification to the existing burial grounds, located in the 218-W-5 low level burial grounds in the northwest portion of the 200 West area of the Department of Energy's (DOE) Hanford Site. The project constructed a radioactive mixed waste disposal facility, which is designated Trench 31 of the Solid Waste Burial Grounds (SWBG) 218-W-5. Trench 31, hereafter known as "the facility," will contain waste designated as low-level radioactive mixed waste (LLMW) produced either at the Hanford Site or by offsite generators. The facility will accept containerized and bulk LLMW. Facility operations will require the use of trucks, forklifts, cranes, bul1dozers, frontloaders, and dust mitigation equipment.

The facility is Resource Conservation and Recovery Act (RCRA) compliant landfill, with a double liner and leachate collection systems. It consists of a rectangular landfill with approximate base dimensions of 76.2 by 30.5 meters (250 by $100 \mathrm{ft}$.$) and a surface grade footprint of 1.3$ hectares ( 3.2 acres). The bottom and sides of the landfill are covered with a .9 meter ( $3 \mathrm{ft}$.) deep operations layer of soil to protect the liner system during fill operations. The floor of the landfill slopes slightly, giving a variable depth of 9.1 to 12.2 meters ( 30 to $40 \mathrm{ft}$. ), allowing drainage to a recessed section at the eastern end that houses the sumps for leachate collection. Pumps are provided in the sump areas, and provide for removal of leachate from the sumps and storage of leachate in a 37,900 liter $(10,000$ gal.) storage tank located at the eastern crest of the landfill, in accordance with regulatory requirements and permit conditions. When a need for transfer of leachate from storage tank arises, the leachate will be sampled to ensure that it meets the waste acceptance criteria of the facility that will accept the leachate for storage. Current plans have the Teachate being stored in the Hanford 200 East area double-she11 tank system.

The Westinghouse Hanford Company (WHC) is the Hanford Site Operating Contractor and is the responsible contractor for facility startup and operation of the leachate collection system.

A project time line overview, from project conception through facility startup, is provided in the table in appendix A. Project conception began in 1987, construction began in 1993, and startup is scheduled to occur in 1995. The operating contractor performed a readiness assessment (RA) and declared readiness for operations to DOE in December 1994.

\section{LESSONS LEARNED SUMMARY}

Upon completion of the RA, the Readiness Assessment Team (RT) reconvened to develop the lessons learned from the project $W-025$ process. The first item of business was to have all personnel who were involved in the project from conception through startup of operations develop a list of things that went very well and things that didn't go well or that need improvement. A11 were free to speak their opinions and viewpoints. No ideas were withheld from the list. The list is provided in appendix B. 
Next, a Recommendation Committee was convened to understand the issues and develop a set of lessons learned and recommendations. The committee was made up of representatives from the projects group, operations organization, and the RT. The issues identified in the initial meeting provided information to develop the necessary background for determining the lessons learned. Additional research was performed by the committee to help determine the causes of the issues. The following are the brief statements of the lessons learned as determined by the committee:

Lesson Learned \#1: It is critical that the correct operations organization of the project be identified before writing the Functional Design Criteria (FDC) and it is critical that the project meets the operational needs and plans of the operations organization. If the end product is not to the satisfaction of the operations organization, the disconnect could be costly. The operations organization must be highly involved in the project from conception through startup.

Recommendation: Develop and publish a project management administrative procedure for use by the division.

Lesson Learned \#2: It was recognized that performing a line-by-1ine review of any published document that may identify requirements, assumptions, and commitments (RACS) with which the facility and operations organization must comply, and publishing the results in a compliance matrix was a great idea. Recommendation: 1) Incorporate into the division's project management administrative procedure. 2) Write and perform an implementation plan for applying this process retroactively to identified RAC documents.

Lesson Learned \#3: If a startup plan is not developed in a timely fashion and is not documented and tracked efficiently by the operations organization, many items required for startup or that would assist in an efficient startup may not get completed.

Recommendation: Write an administrative procedure for use by the division which defines when a startup plan is required and shows how to write a startup plan.

Lesson Learned \#4: A 1ack of guidance on requirements that are applicable to the operating contractor and the lack of coordinated implementation of new requirements on the part of the operating contractor can result in untimely completion of project milestones due to a lack of compliance with requirements.

Recommendation: 1) The division's Standards/Requirements Identification Document (S/RID) will be approved and issued. An organization will be identified to maintain the S/RID as a living document. 2) A Compliance Assessment Plan will be written for assessing the division's compliance with the approved and issued S/RID.

Lesson Learned \#5: Improvements can be made to the RA process for better efficiency and coordination.

Recommendation: Modify the division's operational readiness activities administrative procedure as necessary.

Appendix $C$ of this Lessons Learned Report is devoted to a detailed analysis of the lessons learned. Each lesson learned has a background, a lesson learned statement, and a recommendation statement. 


\section{APPENDIX A: TRENCH 31 (PROJECT W-025) TIME LINE OVERVIEW}

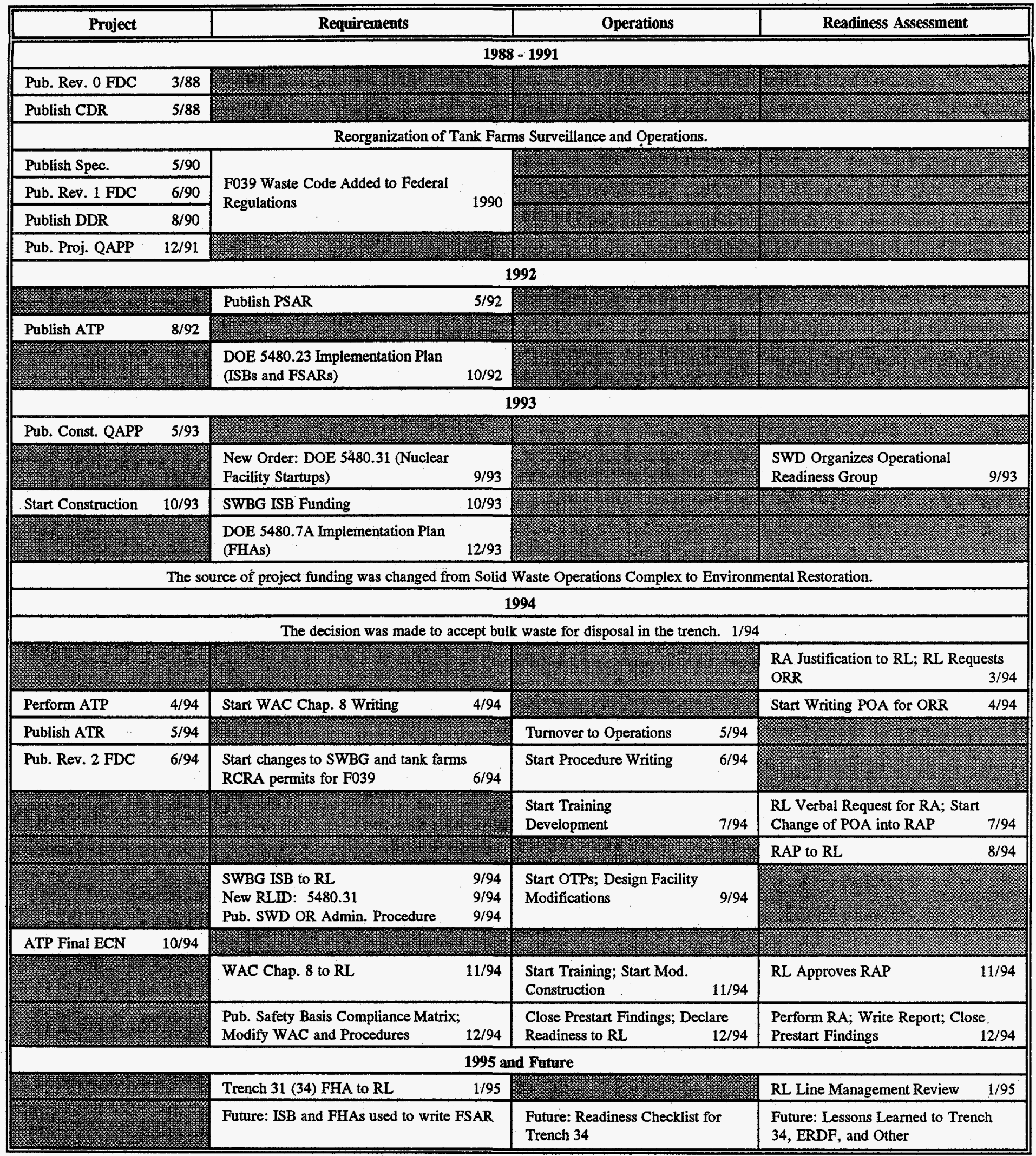




\section{APPENDIX B: PERSONNEL OPINIONS AND VIEWPOINTS}

The following list was developed from statements that were made by various personnel who were involved with various aspects of the project. Note, these were statements that were provided without need for any supportive evidence. A11 personnel were encouraged to speak freely. No statements were withheld from the list. The list was used as a basis to investigate issues further and develop the lessons learned. The list is provided here without any particular attention to chronology or categorization.

\section{THINGS THAT WENT WELL}

The RT reviewed basis documents before the actual start date of the RA; the RT had early planning meetings before the RA started for planning RA schedule, strategy, and lines of inquiry

Assigning an operations organization coordinator for the RA was very helpful

Communication between the operations organization coordinator and the RT coordinator was very good

Operations organization brought in a Startup Engineer

Lessons learned from the Liquid Effluent Retention Facility (LERF) were incorporated into the facility construction

Excellent team work in within a few months of the planned startup date by all involved organizations

A method was developed by the operations organization for ensuring compliance with requirements documents by publishing a matrix for 1 ineby-line compliance

The DOE Richland Operations Office (RL) was in agreement with the division on the interpretation of "new facility" vs. "facility modification" for this type of activity, which reduced the level of review type from an Operational Readiness Review (ORR) to an RA

We will be able to share these lessons learned with other division activities and other sites

The WHC RA was conducted and the report issued in only 2 weeks

Met the contract deliverable (declare readiness to $\mathrm{RL}$ by $12 / 30 / 94$ );

this was accomplished without sacrificing other milestones

The Readiness Assessment Plan (RAP) aided the RT and operations organization in communicating expectations; the RT ensured attention to detail in the facility's readiness; since a detailed RA was performed, the operations organization is comfortable about being ready to operate

$\mathrm{RL}$ recognized the division's ability to review itself 
DOE Headquarters delegated startup approval authority to RL; RL initially considered performing an operational readiness review (ORR), but decided to conduct a low level line management review based upon lessons learned from other reviews

Operations organization assigned an experienced lead nuclear process operator to the project

- Overall construction went well

Operations organization openly communicated with the RT; personnel were quite responsive to RT questions

The operations organization had daily status meetings toward the end

The Operational Test Procedure (OTP) was very beneficial in providing data for procedure development and management of leachate

Operations and maintenance training was developed in record time (short); the training was effective (personnel knew systems, 1ayout, etc.)

- Management involvement overcame bureaucratic hurdles and ensured a quicker response by the modification construction contractor in completing modification construction

The division identified the need for and organized an operational readiness group when the associated DOE Order was issued, prior to implementation plans being developed

The RAP was written and agreements were made with RL while the associated DOE Order was being implemented by RL

\section{THINGS THAT NEED IMPROVEMENT}

Industrial safety audits and inspections were not all formally documented and tracked

The operations organization had less than adequate understanding of the project deliverable early in design

Funding to write the Waste Analysis Plan (WAP) was not timely

Lack of waste forecast and definition

The initial waste acceptance criteria (WAC) review was not thorough

Plans and procedures for sampling and analysis of leachate are inefficient

Lack of alternatives for leachate disposal; leachate disposal was not resolved early enough 
Not all RT members had the final version of the RAP upon commencement of the RA

No realistic schedule; operations organization involvement in design/construction activities was less than adequate; the engineering group of the operations organization didn't initially get involved; lack of attention by the operations organization to involve all required groups; Radiological Controls was not involved early enough; communications and scheduling within the division were less than adequate during FY94; project status/schedule were not clear; the operations organization was slow in getting involved

The milestone for the operating contractor to declare readiness to RL to startup the facility was set prior to gaining an adequate understanding of the things that needed to be accomplished prior to startup

RL didn't give final concurrence on review type until late in the process; RL did not approve the RAP until just prior to starting of the RA

Adequate funding was not provided for timely operations organization involvement in preparation for startup of the facility

Other tasks diverted the operations organization's attention/resources away from the project; it was not an operations organization priority until near to milestone

No clear line of which organizations get involved at what times; not a1l organizations were aligned to meet milestone

No administrative procedure to direct the operations organization on how to obtain readiness; no Operation's Startup $\mathrm{P} 1$ an/No Operating $\mathrm{Plan}$

No time between construction of Trench 31 and 34 to allow lessons learned to be incorporated into the construction/design of Trench 34

$\mathrm{RL}$ was slow on some action responses

There were 3 different Project Engineers during the project construction; excessive personnel turnover occured with all positions throughout the course of the project

The RA Report was not clear in its explanation of some of the deficiencies

All operations organization level 4 managers should have reviewed and commented on the RAP

Change of common work practice in deciding to use Plant Operating Procedures instead of Work Plans

Training instructors were not as involved in the performance portion of the training as they should have been 
The milestone was set at a difficult time (during Holidays and winter weather)

Implementation of new requirements disrupted the project evolution; there was no review of changed requirements prior to the start of construction (e.g. Unreviewed Safety Questions (USQs), F039 waste designation code); lack of coordinated study of scope changes (e.g. bulk waste); lack of guidance on which requirements were applicable

There were several iterations of procedure changes during closeout of RA prestart findings

RCRA permit modifications for the F039 waste code were not made in a timely fashion

There is no cover over the leachate storage tank secondary containment (design/funding/industrial safety issue)

Safety class definition inconsistent over project life (started as SC 3 , changed to SC 4 , then returned to SC 3 ); this was discovered during the course of the RA

The construction contractor which built the modifications (loadout piping, loadout pad, and hand rails) did not meet their schedule

- Industrial Safety inspections during construction completion was less than adequate

Lack of application of good design practices (e.g. leachate storage tank level indicator)

The original liner compatibility study was inadequate

Key organizations were not aware of and did not understand the impact of the Solid Waste Burial Grounds (SWBG) Interim Safety Basis (ISB) until near to the milestone

The Waste Acceptance Criteria (WAC) did not originally consider ISB assumptions and commitments

The facility was not up to the expectations of the operations organization, even though it met the design

Initial construction contract did not require as-built drawings; when the construction contractor was contracted to do as-built drawings, they were not done correctly

Development of procedures and operations and maintenance training was started late, though they were completed in a timely fashion

The final version of the POPs were not adequacy and viability tested by the operators prior to the performance of the POPs for the RT 


\section{APPENDIX C: LESSONS LEARNED DEVELOPMENT}

\section{PROJECT MANAGEMENT}

\section{Background:}

The project was originally planned to be used to dispose of some treated waste from the Waste Receiving and Processing (WRAP) facility and was to be constructed on the same schedule as WRAP. The 200 West area was under the cognizance of Tank Farms Surveillance and Operations at the time of project conception. Development of the Functional Design Criteria (FDC) began in 1987 and was finished in 1988. Just after the FDC was issued, Tank Farms Surveillance and Operations (TFS\&O) Organization was reorganized into two separate divisions, which eventually became what we have today, Solid Waste Disposal (SWD) and Tank Waste Remediation System (TWRS). The project was handled by SWD from this point on. Due to funding shortfalls, construction on the project did not begin until October 1993. The construction was funded by the Environmental Restoration (ER) program, and the project mission was changed to accepting waste from ER decontamination and decommissioning activities. The change in mission also resulted in a change of project scope, since ER required the project to accept waste streams different from those that would come from WRAP. The following is a list of the situations that occurred due to the long project time period, the change in mission and scope, and a lack of communication.

- The identified operations organization changed in 1988 from TFS\&0 to SWD. As a result, the project and operations management underwent some changes. Subsequent changes to various documents were not reviewed by the same job positions. There were numerous engineers and managers during conception/design phases. There were three project engineers during project closeout. This excessive turnover could have caused a loss of project understanding and working relationships/communication, and incorrect statusing.

- A number of new regulatory requirements came into being over this long period of time. Implementation of these requirements was rough due to a lack of guidance on which requirements were applicable. New requirements included Safety Analys is Reports (SARs), Technical Safety Requirements (TSRs), Unreviewed Safety Questions (USQs), Fire Hazards Analyses (FHAs), Operational Readiness Reviews (ORRs), and F039 waste code designation.

- The change in mission and scope in 1993 was not well communicated to the affected organizations in the division. Due to the poor communications, there was no clear identification of which organizations were to get involved at what times. Thus, not all organizations were aligned in a timely fashion to complete their aspects of the project. The status of the project at any given time was not clear to organizations outside of the projects group. Adequate funding was not provided for timely operations organization involvement. The actual startup milestone date was determined late in the process. There was no realistic schedule. Responsible persons and organizations were not correctly identified for action on many items on the schedule. There was little operations organization involvement in the final design and 
construction activities. The Radiological Controls organization was not involved early enough. Alternatives for leachate disposal were not developed in a timely fashion. There was not enough lead time provided for permit preparation and modifications. Key organizations were not aware of and did not understand the impact of the Solid Waste Burial Grounds (SWBG) Interim Safety Basis (ISB) until near to the deliverable date for startup. There was a lack of a timely safety review. The waste acceptance criteria (WAC) for LLMW 1 ined landfill disposal was not developed in a timely fashion. Development of procedures and operations and maintenance training was started late, though they were completed in a timely fashion.

The result of all of this was:

- an FDC that did not meet all the needs and expectations of the operations organization; and

- much last minute effort and overtime by all involved organizations to align the project to the operations organization's needs and meet the startup milestone deliverable, which equated to unanticipated expenses.

\section{Lesson Learned:}

It is critical that the correct operations organization of the project be identified before writing the FDC and it is critical that the project meets the operational needs and plans of the operations organization. If the end product is not to the satisfaction of the operations organization, the disconnect could be costly. Thus, it is crucial that the operations organization be highly involved in the project from conception to completion. There are situations that can reduce the effectiveness of operations organization involvement. First, operational needs and plans are normally passed on to the projects group through the operations organization's review and approval authority over the FDC. If the operational needs and $\mathrm{pl}$ ans are not well defined or understood by the operations organization personnel who review the FDC, or if the operations organization which performs the review is not the operations organization that will be operating the facility, then the review cycle is of little value to ensuring that the end product is ready for operations. Second, when key personnel turnover occurs or the operations organization undergoes changes, if the operational needs and plans for the project are not well communicated, the original plans may be lost or confused during turnover. Third, if the mission and/or scope of the project changes, or if new regulatory requirements or lessons learned surface, and the original operational needs and plans are not documented, it is difficult for the operations organization to analyze how the FDC should be modified to be consistent with the new mission/scope/requirements and the resulting new operational needs and plans.

\section{Recommendation:}

WHC-CM-6-2, Project Management, identifies TWRS, Construction Projects, as the organization who provides the project services. As such, WHC-CM-6-2 fits the management structure of TWRS, but is lacking in defining how the division should manage its own projects within its own management structure. The division should develop and publish a Project Management section for WHC-CM-5- 
34, Solid Waste Disposal Operations Administration. Such an administrative procedure would reference WHC-CM-6-1, Standard Engineering Practices, and WHCCM-6-2 for information on project documentation, to minimize duplication of requirements in WHC manuals, but it would detail specifics of how the division conducts its project management. This administrative procedure should contain and do the following:

- identify Responsible Positions and define job responsibilities; the following responsible positions should be identified, as a minimum:

- Product Line Manager (PLM),

- Facility Cognizant Engineer,

- Project Engineer,

- Safety Analysis Representative,

- Environmental Comp1iance Officer,

- Safety Oversight Representative,

- Quality Assurance Representative,

- New Requirements Coordinator,

- Startup Coordinator, and

- Operational Readiness Coordinator;

- provide and suggest use of Responsible Position Turnover Checklists: these checklists identify the points of discussion that are important for adequate project position turnover;

- describe and require a Project Coordination Task Schedule; such a schedule would be in the level 4 product line schedule; it would contain project development, safety analysis, construction, oversight, operations, operations support, and operational readiness activity tasks;

- provide Project Development Flowcharts; these would show how all of the minimum scheduling requirements fit together for various types of projects (e.g. major projects, minor projects, general plant projects);

- describe and require Periodic Planning Meetings; these meetings would be initially held monthly; as project completion and startup approaches, the meetings will be switched to weekly and finally, daily; the PLM will run these meetings and all reports on progress throughout the project will be made to the PLM; level 5 scheduling detail should be discussed in these meetings, so that the PLM may assign priority to tasks, as necessary;

- describe and suggest use of an Operating Basis; an Operating Basis would be drafted by the facility prior to the functional design criteria phase; it would provide information important to how the facility will be operated when the project is complete; it provides the basis against which the facility performs reviews of the project design documentation; it provides the minimum specification requirements (e.g. as-built drawings, use of best available technology, etc.) it would be revised as necessary to incorporate information that is obtained during the project phase;

- describe and suggest use of Compliance Matrices; a compliance matrix is a document that identifies the requirements, assumptions, and 
commitments (RACs) made in an associated requirements document, and identifies where they are to be implemented; it is developed by performing a line-by-line review of a given requirements document and gleaning all RACs stated in the document; it then allows the facility to plan where the RACs will be implemented; it is a way of ensuring that no RACs are missed in the project development; it also provides an auditable record for readiness review activities; the compliance matrices would be addenda to the Operating Basis; and

- describe the method of change control: whenever a change in mission or scope occurs as a result of changes in funding, RACs, lessons learned, etc., the PLM will inform all responsible positions by a formal method; Engineering Change Notices (ECNs) wi11 be made to the Operating Basis and FDC, as necessary; all ECNs will be reviewed and approved by the same responsible positions that reviewed and approved the original documentation.

\section{REQUIREMENTS IMPLEMENTATION}

\section{Background:}

During the Readiness Assessment Team (RT) documentation review for preparation for the readiness assessment (RA), it was discovered that an administrative TSR in the ISB required, "A program...to ensure that specific assumptions and commitments made in the SWBG ISB..." A request was made by the RT to the facility management that the RT be provided with some assurance that this had been done. "This was linked with the RA prerequisite, "Safety limits identified in the authorization basis have been incorporated in operating documents." In the final days leading up to the commencement of the Readiness Assessment, a method was developed for ensuring implementation of TSRs, assumptions, and commitments that were identified in the ISB documents. A line-by-1ine review was conducted of the ISB, and a matrix was published which identified each of the TSRs, assumptions, and commitments, and where they were implemented (e.g. plant operating procedures, waste acceptance criteria, etc.).

\section{Lesson Learned:}

It was recognized that publishing a Compliance Matrix would be a good thing to do for any published document that may identify RACs that the facility must live up to. It was recognized that this process would be most valuable when performed proactively as a planning tool, so that the process would identify where RACs are to be implemented. It was also recognized that this method of RAC identification provided an auditable trail for oversight and readiness reviews.

Recommendation:

1) This process is recommended above for incorporation into the division's project management administrative procedure. 
2) Write and perform an implementation plan for applying this process retroactively to identified RAC documents (e.g. authorization bases, Records of Decision, Resource Conservation and Recovery Act (RCRA) permits, etc.).

\section{STARTUP PLANNING}

\section{Background:}

The operations organization was provided funding in early calendar year 1994 to prepare for startup of the completed facility. A schedule for completion of major items was developed, but it did not have the detail necessary to identify all items that needed to be done to prepare the facility for startup. It also did not always identify the correct responsible parties for completion of various schedule items. The periodic status meetings that were held did not have all of the relevant responsible parties present to status the schedule. The scheduler was never present at the status meetings. Updates to the schedule were made more than a month behind. The result was a lack of coordination between the operations organization and supporting organizations in preparing for startup. By the time the readiness assessment plan (RAP) was written, there was still no full schedule for use in obtaining readiness to startup. Shortly thereafter, the operations organization identified a coordinator to work directly with the RT and to ensure that the facility gained readiness. This caused a great improvement in the schedule and in the efforts to get ready. However, the final schedule was more a result of the operations organization trying to meet the prerequisites identified in the RAP, and not their own identification of everything that needed to be done. As a result, many items that needed to be completed were not identified in a timely fashion. A few items were not identified by the operations organization and were discovered by the RT as shortcomings.

\section{Lesson Learned:}

If a startup plan is not developed in a timely fashion and is not documented and tracked efficiently by the operations organization, many items required for startup or that would assist in an efficient startup may not get completed.

\section{Recommendation:}

1) Write an administrative procedure to be added to WHC-IP-1048, Operational Readiness Activities, which defines when a startup plan is required and shows how to write a startup plan.

2) Incorporate the requirements for a startup plan into the WHC-CM-5-34, section 1.4, Operational Readiness Activities.

\section{REQUIREMENTS IDENTIFICATION}

\section{Background:}

Implementation of new requirements disrupted the project evolution. There was a lack of guidance on which requirements were applicable. The following are some examples of this problem. 
In May of 1992, the Preliminary SAR (PSAR) was published for the project. The PSAR addressed disposal of waste from the WRAP facility. In October of that same year, WHC published the Implementation Plan for DOE Orders 5480.21. .22, and .23, new safety analysis requirements for nuclear facilities (USQ, TSRs, and Nuclear SARs). At the end of calendar year 1993, when funding was provided to write an ISB for the SWBG (in accordance with the implementation plan) the mission of the project changed to accepting waste from ER. The decision was made to incorporate the safety analysis for the project into the SWBG ISB. This decision was not well communicated. In early calendar year 1994, the decision was made to accept uncontainerized bulk waste. This decision was not well communicated. One example that exhibits the poor communication is that Nuclear Facilities Safety continued to review project documentation as if the original PSAR was still in force until October, 1994. Since the original PSAR did not address uncontainerized bulk waste, this caused problems in consistency in the review cycle of many documents that were being completed in 1994 .

In December of 1993, the Implementation Plan for DOE 5480.7A, Fire Hazards Analyses, was published. It consisted of a single page internal memo providing cost estimates and identifying operations organization facilities that needed FHAs. It was not clear whether an FHA was a prestart requirement for the facility. The SWBG ISB deferred analysis of a fire propagation issue to the SWBG FHA. This statement was made in the Mixed Waste Trench portion of the ISB, which implied that the FHA needed to be written and approved prior to startup of the facility. In September, 1994, an administrative procedure was written, WHC-SD-GN-FHA-30001, Integration of Fire Hazards Analysis and Safety Analysis Report Requirements. This procedure identified how to perform FHAs to support safety analysis reports. Sometime in late calendar year 1994, the decision was made that the FHA would be used with the ISB to write the Final SAR (FSAR), which was to occur after startup of the facility per the Safety Analysis Requirements Implementation Plan. Thus, the FHA was not a prestart requirement for the facility.

In September, 1993, DOE 5480.31, Startup and Restart of Nuclear Facilities, was issued. In November, DOE-STD-3006-93, Planning and Conduct of Operational Readiness Reviews, was issued. In. March, 1994, planning commenced for a RA to be performed on the project. RL directed that an ORR be performed.

Operations organization, assisted by the operational readiness group, commenced writing a PIan of Action, as required for an ORR per the order. In July, lessons learned from the 222-S Laboratory Startup moved RL to go with the original WHC plans for an RA. By August, the RAP had been submitted to RL for approval. In September, the division published its administrative procedure for conduct of Operational Readiness Activities, in accordance with the DOE order and the standard. Concurrent7y, RL published its RL Implementing Directive (RLID) for the order. In November, RL approved the RAP and use of the division's Operational Readiness Activity procedure in place of the RLID, since the RLID had not yet been implemented in the WHC contract.

Approval of the RAP occurred very close to the startup deliverable date. As a result of this and the fact that not all operations organization level 4 managers and support organizations understood the level of detail involved in the RA prior to approval of the RAP, there was much last minute work that was performed to bring the facility up to the readiness standards of the RAP. 
In 1990, the F039 waste designation code was added to federal regulations, for designation of leachate from a hazardous waste landfil1. To this date, F039 has not been added to the Washington Administrative Code. This project was the first RCRA compliant hazardous waste lined landfill in the state of Washington, and only the second RCRA compliant mixed waste lined landfill in the country. The lack of experience with RCRA compliant hazardous waste lined landfills caused a misinterpretation of the F039 waste code definition. Initially, the F039 waste code was thought to apply only to leachate from landfills in which the waste was not characterized. In the summer of 1994 , the true definition became clear and it was determined that the leachate out of this facility would be F039. Thus, change requests for the SWBG and tank farms RCRA permits to include F039 did not commence until the summer of 1994.

\section{Lessons Learned:}

A lack of guidance on requirements that are applicable to the operating contractor and the lack of coordinated implementation of new requirements on the part of the operating contractor can result in untimely completion of project milestones due to a lack of compliance with requirements.

\section{Recommendation:}

A Standards/Requirements Identification Document (S/RID) for the division has already been written and has been sent to DOE for approval. This document identifies all standards and requirements that the division is to live by.

1) An organization should be identified to maintain the S/RID as a living document.

2) A Compliance Assessment Plan should be written for assessing the division's compliance with the approved and issued S/RID.

\section{OPERATIONAL READINESS ACTIVITIES}

\section{Background:}

In 1994, while RL was working on developing the RLID for DOE 5480.31, the division's operational readiness group was developing division procedures for operational readiness activities. Concurrent with the writing of these procedures, the division convened an RT and wrote the RAP for the facility startup. This RA was the first independent review activity that the division conducted in accordance with the new procedures. Considering the concurrent development of procedures and use of the procedures, the RA went extremely wel1.

\section{Lessons Learned:}

Some things were done that worked very well and some areas for improvement were identified. Improvements can be made to the RA process for better efficiency and coordination.

Recommendation: 
Changes should be made to WHC-CM-5-34, section 1.4 , and WHC-IP-1048, to incorporate the lessons learned described in the following statements.

- RT members went through a learning curve on how to write review summaries while the report was being written. Examples should be provided to the RT members in advance of the commencement of the review of model review summaries.

- The RT agreed to all corrective actions and held signature authority over closeout of all findings. This was excessive, since many of the findings had priority planning grid (PPG) values less than 6 . Corrective action management for prestart and poststart findings should be performed per WHC-CM-1-4, Corrective Action Management Manua 7 , and the WHC-CM-5-34, section 1.22, Corrective Action Management. The review plan shall define the specific agreements for the specific review, as allowed by the administrative procedures.

- There was a lack of understanding of the findings on the part of some facility personnel responsible for defining and performing corrective actions. This was partially due to a lack of full details being provided in the review report. The agreements in the review plan should specify that the RT attend the Corrective Action Evaluation Group (CAEG) meetings to provide detailed explanation of the findings so that the issues may be fully understood, correct PPG values assigned, and adequate corrective actions identified.

- A facility coordinator and RT coordinator were identified months before the RA commenced. This worked very we17. Administrative procedures should identify the positions of Facility Startup Coordinator and Review Team Coordinator.

- Not all level 4 managers reviewed the RAP. This resulted in a lack of their understanding what was required of them. Ensure the appropriate personnel review and approve the review plan.

- The RT wrote the whole report after the RA was completed. The time to write the report could have been reduced by three days if a report shell had been written in advance. The report shell would contain everything except details in the review summaries, the findings, and the lessons learned.

- Within months of the commencement of the RA, the RT reviewed the available documentation. This helped in a number of ways and should be done in future review activities. This pre-review accomplishes training the RT in the specifics associated with the facility. It also helps the RT identify potential issues, so that when the review is commenced, the RT is able to immediately pursue performing the review in valid, meaningful directions. This shortens the time needed for the review. Finally, it helps the RT identify holes in the review plan, and thus, adjust plans for the conduct of the review to ensure that all review objectives are adequately covered.

- The RT developed a day-by-day schedule prior to the commencement of the review. It was recognized that the facility could have better 
prepared for the review if the schedule had been issued earlier in the review plan. The review plan should contain a day-by-day schedule for conduct of the review. It should also specifically identify the operations that the facility is to perform for the review. It should specify whether the RT or the facility will determine the drills to be performed. 